Article

\title{
Combustion, Performance, and Emission Behaviors of Biodiesel Fueled Diesel Engine with the Impact of Alumina Nanoparticle as an Additive
}

\author{
Srinivasan Senthil Kumar ${ }^{1, *}$, K. Rajan ${ }^{2, *}$, Vinayagam Mohanavel ${ }^{3} \mathbb{D}$, Manickam Ravichandran ${ }^{4}$, \\ Parvathy Rajendran 5,6,*(D), Ahmad Rashedi ${ }^{7}(\mathbb{D})$, Abhishek Sharma ${ }^{8, *}$, , Sher Afghan Khan 9 \\ and Asif Afzal 10,11,*iD
}

check for updates

Citation: Kumar, S.S.; Rajan, K.; Mohanavel, V.; Ravichandran, M.; Rajendran, P.; Rashedi, A.; Sharma, A.; Khan, S.A.; Afzal, A. Combustion, Performance, and Emission Behaviors of Biodiesel Fueled Diesel Engine with the Impact of Alumina Nanoparticle as an Additive. Sustainability 2021, 13, 12103. https:/ / doi.org/10.3390/su132112103

Academic Editor: Talal Yusaf

Received: 26 August 2021

Accepted: 28 October 2021

Published: 2 November 2021

Publisher's Note: MDPI stays neutral with regard to jurisdictional claims in published maps and institutional affiliations.

Copyright: (c) 2021 by the authors. Licensee MDPI, Basel, Switzerland. This article is an open access article distributed under the terms and conditions of the Creative Commons Attribution (CC BY) license (https:/ / creativecommons.org/licenses/by/ $4.0 /)$.
1 Department of Mechanical Engineering, RMK College of Engineering and Technology, Chennai 601206, India 2 Department of Mechanical Engineering, Dr. M.G.R. Educational and Research Institute, Chennai 600095, India

3 Centre for Materials Engineering and Regenerative Medicine, Bharath Institute of Higher Education and Research, Chennai 600073, India; mohanavel2k16@gmail.com

4 Department of Mechanical Engineering, K Ramakrishnan College of Engineering, Trichy 621112, India; smravichandran@hotmail.com

5 School of Aerospace Engineering, Universiti Sains Malaysia, Engineering Campus, Nibong Tebal 14300, Malaysia

6 Faculty of Engineering \& Computing, First City University College, Bandar Utama, Petaling Jaya 47800, Malaysia

7 School of Mechanical \& Aerospace Engineering, Nanyang Technological University, 50 Nanyang Avenue, Singapore 639798, Singapore; amma0002@e.ntu.edu.sg

8 Department of Mechanical Engineering, Manipal University Jaipur, Jaipur 303007, India

9 Department of Mechanical Engineering, Faculty of Engineering, International Islamic University, Kuala Lumpur 44000, Malaysia; sakhan06@gmail.com

10 Department of Mechanical Engineering, P. A. College of Engineering, Visvesvaraya Technological University, Mangaluru 574153, India

11 Department of Mechanical Engineering, School of Technology, Glocal University, Delhi-Yamunotri Marg, SH-57, Mirzapur Pole, Saharanpur District, Uttar Pradesh 247121, India

* Correspondence: sskumar.rmkcet@gmail.com (S.S.K.); krajanmech@gmail.com (K.R.); aeparvathy@usm.my (P.R.); drasharma58@gmail.com (A.S.); asif.afzal86@gmail.com (A.A.)

\begin{abstract}
The objective of this research work is to evaluate the performance, combustion, and exhaust emissions of a variable compression ratio diesel engine utilizing diesel $25 \%$ rubber seed biodiesel mixture (B25) blended with $25 \mathrm{ppm}$ and $50 \mathrm{ppm}$ of alumina nanoparticle running with different operating conditions. An ultrasonicator was used to make uniform dispersion of alumina (Al) nanoparticles in the diesel-biodiesel mixture. Biodiesel mixture blended with nanoparticles has physicochemical characteristics that are comparable to ASTM (American Society for Testing and Materials) D6751 limitations. The results revealed that the B25 exhibited a lower cylinder peak pressure and lower HRR (heat release rate) than diesel at maximum power. BTE (brake thermal efficiency) of B25 is 2.2\% lower than diesel, whereas BSFC of B25 is increased by $6 \%$ in contrast to diesel. Emissions of HC (hydrocarbon), CO (carbon monoxide), and smoke for B25 were diminished, while emissions of NOx (nitrogen oxide) were higher at maximum power. Further, the combustion and performance of diesel engine were improved with the inclusion of alumina nanoparticles to biodiesel blends. In comparison to B25, BTE of B25 with 50\% alumina nanoparticles (B25A150) mixture was enhanced by $4.8 \%$, and the BSFC was diminished by $8.5 \%$, while $\mathrm{HC}, \mathrm{CO}$, and smoke were also diminished by $36 \%, 20 \%$, and $44 \%$, respectively. At peak load, the maximum cylinder pressure and HRR of B25 were improved by $4.2 \%$ and $6.7 \%$, respectively, with the presence of $50 \%$ alumina nanoparticles in a biodiesel blend (B25A150).
\end{abstract}

Keywords: alumina nanoparticle; biodiesel; diesel engine; performance; emission; combustion 


\section{Introduction}

Rapid expansion in the transportation industry as a result of modernization and industrialization raises energy consumption and increases emissions from engines, which degrade the environment internationally. IC (internal combustion) engines are primarily employed in the automotive, power generation, and agricultural industries due to their lower fuel economy. Using fossil fuels results in increasing amounts of $\mathrm{HC}, \mathrm{CO}$, and $\mathrm{NOx}$ emissions, all of which contribute to global climate change [1,2]. As a result, numerous academic researches has been active in the search for alternatives to diesel fuel, such as alcohols, vegetable oils, and its derivatives. Vegetable oils are biodegradable and non-toxic; however, they have high viscosity and low volatility, which cause poor atomization leading to incomplete combustion, engine deposits, high smoke emissions, and low brake thermal efficiency when used in CI (compression ignition) engines [3]. Transesterification is the process of converting vegetable oil (triglycerides) into monoester. This process results in a significant reduction of viscosity and density, thereby improving thermal efficiency and low smoke levels. Converting these oils into biodiesel further increases the price, making it an unviable fuel for developing countries, such as India. Non-edible oils such as castor, karanja, neem, rubber seed, and jatropha are available in large quantities in India, and they can be easily converted to biodiesel at low cost. In this research, the rubber seed oil is taken as the fuel and alumina nanoparticles as the fuel additive to enhance the combustion in a diesel engine. Rubber seed oil produced from the rubber tree (Hevea brasiliensis) belongs to the Euphorbiaceae family. It originated from South America and has been cultivated in Southeast Asia since the 18th century [4]. It is a prominent plantation crop that holds vital economic importance for India. The tree provides not only rubber latex but also a variety of ancillary products, with rubber seed being one of them. The oil extracted has application limited to soap and lubricating industries. The rubber seed oil has $17-20 \%$ saturated fatty acids, $17-22 \%$ unsaturated fatty acids, and viscosity of more than $30 \mathrm{cSt}$. As a result, the rubber seed oil as a fuel has less thermal efficiency and increased smoke emission compared to diesel [5].

Jun Cong Ge et al. [6] studied the performance of CRDI (Common rail direct fuel injection) diesel engines with EGR rates and pilot injection timings using palm oil biodiesel blends under $25 \%$ and $75 \%$ engine loads. B30 blend with a 10\% EGR (exhaust gas recirculation) rate, or with a pilot injection timing of $24^{\circ}$ BTDC (Before Top-Dead-Center), can effectively reduce PM (particulate matters) emissions and simultaneously keep NOx emissions at a low level. Jun Cong Ge et al. [7] investigated the volatile organic compounds (VOCs) in the exhaust emissions from a common rail diesel engine fueled with diesel and B20 canola oil biodiesel blends at various engine loads. Results indicated that the regulated emissions of $\mathrm{CO}, \mathrm{HC}$, and PM were decreased, and the total VOC emissions of B20 were lower than those with the other test fuels. Jun Cong Ge et al. [8] investigated the soot particle distribution and regulated and unregulated emissions in a CRDI diesel engine using diesel and palm oil biodiesel blends. It was found that all the PM particles were less than $100 \mathrm{~nm}$ in diameter observed by TEM (Transmission electron microscopy), and the average diameters of primary particles were distributed between 20 and $26 \mathrm{~nm}$. Unregulated emissions such as trace metals, e.g., $\mathrm{Pb}, \mathrm{Mn}$, and $\mathrm{Ba}$, were found in the $\mathrm{PM}$ particles, and the xylene, toluene, and benzene unregulated emissions of B100 were reduced compared to diesel.

Many studies have suggested utilizing biofuel as an alternate fuel for diesel engines, which results in a reduction of BTE and poor burning characteristics as compared to diesel [9]. The benefits of biodiesel are compromised by higher NOx emissions and decreased BTE. Vallinayagam et al. [10] tested the pine oil-diesel mixtures in diesel engines and found that pure pine oil lowered the emissions of $\mathrm{CO}, \mathrm{HC}$, and smoke. An experimental investigation was carried out by Bajpai et al. [11] with a conventional diesel engine using different blends of Karanja biodiesel such as $5 \%, 10 \%, 15 \%$, and $20 \%$ by $v / v$ ratio with diesel at varying engine loads. They reported $\mathrm{CO}, \mathrm{HC}$, and smoke emission (except NOx) decreases but also BTE decreases with increasing karanja biodiesel blends. By 
considering performance and emission level, they concluded that $10 \%$ biodiesel blend was the optimum blend for biodiesel operation. Similarly, Mahanta et al. [12] also studied the engine performance by using pongamia pinnata methyl ester as a biodiesel blend at $5 \%, 10 \%, 15 \%, 20 \%, 25 \%$, and $30 \% v / v$ ratio. They also experienced similar results for $\mathrm{CO}, \mathrm{HC}$, and smoke (except NOx) emission, with all blends suggesting that B20 fuel was the optimum blend. Rajan et al. [13] evaluated the performance of diesel engines using biodiesel at various injection pressures and reported lower levels of exhaust emissions except for NOx at higher Ips (injection pressure). Ravichandran et al. [14] investigated the engine performance by employing a corn oil methyl ester mixture, which produced greater NOx emissions while lowering other pollutants when compared to diesel.

Different researchers and scientists have studied to reduce NOx emissions with an oxygenated substance such as alcohol or ether can be added to diesel/biodiesel mixes [15-17]. DEE (Diethyl ether) is a great combustion booster that has a lower auto ignition temperature. Rajan et al. [16] evaluated engine performance under varied loading conditions utilizing pure Karanja biodiesel with $10 \%$ and 15\% DEE blends. They reported that there is a substantial drop in NO and smoke for pure Karanja biodiesel using 15\% DEE mixture as well as a drop in cylinder peak cylinder pressure and HRR contrast to pure biodiesel. It has been suggested that the optimal percentage is $15 \%$ since it resulted in the best engine performance [18] analyzed the role of 10\% DEE into diesel-biodiesel-ethanol and dieselbiodiesel-methanol mixtures. Introducing DEE to a diesel-biodiesel-ethanol combination boosted the period of combustion, cylinder pressure, and BSFC while lowering the emissions of NOx and smoke, according to their findings [19]. Lee and Kim [20] reported that introducing DEE to diesel in different ratios has no influence on engine BTE. Results also revealed that $\mathrm{HC}$ and $\mathrm{CO}$ emissions were diminished with increase in emissions of NOx.

Consequently, several scholars have concentrated their efforts on various nanoparticle blended biodiesel to achieve better performance with a decrease in emissions. Working characteristics of biodiesel in the engine were improved by the inclusion of nanoparticles with biodiesel [21-23]. Nandhagopal et al. [24] evaluated the performance characteristics of an engine operated on biodiesel utilizing $\mathrm{TiO}_{2}$ (titanium dioxide) and $\mathrm{ZnO}$ (zinc oxide) nanoparticle emulsions. Their findings resulted in higher BTE and a decrease in overall emissions. Nafaji [25] evaluated the impact of varying nanoparticle proportions mixed in biodiesel on the performance behavior of diesel engines and determined that performance and emissions were equivalent to diesel. Patel and Kumar [26] investigated the role of Alumina $\left(\mathrm{Al}_{2} \mathrm{O}_{3}\right)$ nanoparticles as additives with Jatropha biodiesel on diesel engines and revealed a significant improvement in BTE as well as a drastic decline in emissions of $\mathrm{NO}, \mathrm{CO}, \mathrm{HC}$, and smoke. Vellaiyan et al. [27] used an $\mathrm{Al}_{2} \mathrm{O}_{3}$ nanoparticle additive to study the combustion process of water-emulsified biodiesel used in a diesel engine. Their findings revealed that water-emulsified soybean biodiesel substantially enhances the cylinder pressure and HRR when contrasted to biodiesel. It also diminishes the emissions of $\mathrm{NOx}$, smoke, $\mathrm{HC}$, and $\mathrm{CO}$ while increasing total $\mathrm{CO}_{2}$. Srinivasan et al. [28] studied the combustion process of an engine utilizing neat biodiesel mixed with $25 \mathrm{ppm}$ and 50 ppm alumina and titanium oxide nanoparticles, and their findings indicated that the BTE was raised and the BSFC decreased with 50 ppm $\mathrm{TiO}_{2}$ nanoparticle blended biodiesel. Emissions of $\mathrm{CO}$, smoke, and $\mathrm{HC}$ were declined, but NOx emissions were increased when compared to B25.

Arul Mozhi Selvan et al. [29] evaluated the performance of CI engines utilizing diesel and diesel-biodiesel-ethanol mixtures using $\mathrm{CeO}$ (cerium oxide) nanoparticles as an additive. It has been observed that adding $\mathrm{CeO}$ to diesel ethanol mixtures enhances the overall BTE while decreasing $\mathrm{CO}, \mathrm{HC}, \mathrm{NO}$, and smoke. Annamalai et al. [30] tested an engine utilizing a Lemongrass oil (LGO))-CeO nanoparticle emulsion and reported that the BTE was increased with LGO-CeO nanoparticle and its emulsions due to its larger surface area of nanoparticles. There is a substantial reduction in $\mathrm{CO}, \mathrm{HC}, \mathrm{NOx}$, and smoke emissions when compared to LGO and its emulsion and diesel. Yuvarajan et al. [31] investigated the combustion process of pure biodiesel coupled with an $\mathrm{Ag}_{2} \mathrm{O}$ nanoparticle 
under various operating conditions. There was an increase in BTE with a drop in BSFC and an improvement in all tail pipe emissions using $\mathrm{Ag}_{2} \mathrm{O}$ (silver oxide) nanoparticles. Yuvarajan et al. [32] analyzed the performance of mahua biodiesel-fueled diesel engine with $100 \mathrm{ppm}$ of copper oxide nanoparticle $(10$ and $20 \mathrm{~nm}$ ) blended with biodiesel and reported that inclusion of $20 \mathrm{~nm}$ particle size improves the BSFC (brake specific fuel consumption) and BTE contrast to $100 \%$ biodiesel with $10 \mathrm{~nm}$ size of copper oxide nanoparticle, whereas $\mathrm{CO}$, smoke and HC were diminished, but NOx was increased.

Based on the literature and experimental studies of various researchers, the analysis of metal oxide nanoparticle additive added with biodiesel revealed that nanoparticle enhance the engine operating characteristics and emission characteristics. $\mathrm{CO}, \mathrm{HC}$, and smoke emissions were considerably reduced to an appreciable limit by the use of nanoparticle added biodiesel. Hence, the current research objective is to evaluate the performance characteristics of a CI engine fueled with a B25 combined with alumina nanoparticles in various concentrations such as $25 \mathrm{ppm}$ and $50 \mathrm{ppm}$ (particle per million), and the results were compared to base fuels.

\section{Materials and Methods}

\subsection{Rubber Seed Tree}

Rubber tree (Hevea brasiliensis) belongs to Euphorbiaceae family. It originated from South America and has been cultivated in Southeast Asia since 1876. The tree grows rapidly at altitudes below $200 \mathrm{~m}$ at temperatures of about $27-30{ }^{\circ} \mathrm{C}$ [2]. It is a prominent plantation crop that holds vital economic importance for India. The tree provides not only rubber latex but also a variety of ancillary products, rubber seed being one of them. The production of rubber seed is $150 \mathrm{~kg} / \mathrm{ha}$ in India. The average oil yield from the seed is from $40 \%$ to $60 \%$ of the kernel by weight. The oil extracted has application limited to soap and lubricating industries. Rubber seed oil has $17-20 \%$ saturated fatty acids, $17-22 \%$ unsaturated fatty acids, and viscosity of more than $30 \mathrm{cSt}$ [4].

\subsection{Preparation of Rubber Seed Oil Biodiesel}

Transesterification is a process of lowering the viscosity of vegetable oil in which raw rubber seed oil (RSO) combines with alcohol in the presence of a catalyst to generate mono ester. In this study, RSO (methanol catalyzed by sodium hydroxide) is used to obtain RSO biodiesel. The amount of sodium hydroxide needed as an impetus for each liter of rubber seed oil was determined to be $10 \mathrm{~g}$ (by titration). For each liter of RSO, $200 \mathrm{~mL}$ of methanol and $10 \mathrm{~g}$ of sodium hydroxide were added, and the chemical reactions were kept at $65^{\circ} \mathrm{C}$, stirring at a constant speed $500 \mathrm{rpm}$ for $60 \mathrm{~min}$. Two layers were formed; solid glycerol sediment in the bottom and the liquid mono ester is on the top the flask. The ester was then rinsed with hot distilled water to remove methanol from biodiesel. Table 1 lists the essential characteristics of biodiesel and diesel fuel. The heating value of biodiesel was found by using bomb calorimeter. Rubber seed oil biodiesel has a calorific value of $38,830 \mathrm{~kJ} / \mathrm{kg}$, which is 9.4 percent lower than regular diesel. The Redwood viscometer was used to measure the kinematic viscosity, and the value obtained for RSME (root-mean-square error) was 5.19 centistokes, which is $38 \%$ higher than diesel. The biodiesel's flash point and fire point were determined using the Pensky Martin equipment. Because of its high viscosity, biodiesel had a greater flash and fire point than diesel fuel. 
Table 1. Fuel's properties.

\begin{tabular}{ccccc}
\hline Properties & Diesel & RSO & RSME & ASTM \\
\hline Density $\left(\mathrm{kg} \mathrm{m}^{-3}\right)$ & 830 & 920 & 882 & D4052 \\
\hline Kinematic viscosity & 3.4 & 52 & 4.7 & D445 \\
\hline Flash point $\left({ }^{\circ} \mathrm{C}\right)$ & 52 & 175 & 157 & D93 \\
\hline Fire point $\left({ }^{\circ} \mathrm{C}\right)$ & 60 & 184 & 163 & D93 \\
\hline Calorific value $\left(\mathrm{MJkg}^{-1}\right)$ & 43 & 36.55 & 38.83 & D240 \\
\hline Cetane number & 48 & 38 & 52 & D976 \\
\hline Oxygen $(\mathrm{wt})$ & - & 11 & 11 & D943
\end{tabular}

\subsection{Preparation of Nanoparticles}

\subsubsection{Alumina Nanoparticles}

Alumina nanoparticle was produced using the sol-gel approach. Deionized water and aluminum nitrate were decomposed with citric acid in a concentration ratio of 0.5 (citrate/nitrate $=0.5$ ) during the procedure. Over several hours, the solution was continually agitated at $60^{\circ} \mathrm{C}$ until it formed a golden yellow sol. The mixture was then warmed to $80^{\circ} \mathrm{C}$ while being constantly stirred until a crystalline gel formed and dried for $12 \mathrm{~h}$ in a $90{ }^{\circ} \mathrm{C}$ furnace.

\subsubsection{Preparation Biodiesel-Nanoparticles Mixtures}

The alumina nanoparticles with an average size of $50 \mathrm{~nm}$ were procured from Reinste Nano Ventures Private Ltd., New Delhi, India. Nanoparticles, in particular, have a large surface. Figure 1 shows pictures taken using a scanning electron microscope (SEM) to examine the structure of $\mathrm{Al}_{2} \mathrm{O}_{3}$ nanoparticles. SEM (scanning electron microscope) scans of both nanoparticles show that they are spherical in shape, have a smooth surface, and have an average particle size of $50 \mathrm{~nm}$. Span 80 was used as a surfactant and to create a sufficient binding with the base fuel to make nanoparticles stable in liquid fuel. Ultrasonication is a great way to enhance particle dispersion and create more homogeneous and stable mixtures. A measured quantity of nanoparticles (25 ppm and $50 \mathrm{ppm}$ ) and a $2 \mathrm{~mL}$ Span80 solution were introduced to biodiesel to form a sustainable biodiesel-alumina nanoparticle mixture, which was then stirred for $45 \mathrm{~min}$ with an ultrasonicator set to $30 \mathrm{kHz}$. In this study, the test fuels B25Al25 (25\% RSME and 25 ppm $\mathrm{Al}_{2} \mathrm{O}_{3}$ nanoparticles) and $\mathrm{B} 25 \mathrm{Al} 50$ (25\% RSME and nanoparticles) were utilized. Figure 1 is an SEM picture of an alumina nanoparticle. The altered biodiesel was analyzed four strokes direct injection air cooled diesel engine at different loads, giving no time for the deposit to form. Hielscher's ultrasonic processing bath was used to perform proper feasibility tests on the ultrasonicator.

\subsection{Test Engine Setup and Procedure}

The engine test was conducted on a Kirloskar diesel engine and connected to a dynamometer to apply the load. Figure 2 depicts a schematic diagram of the engine test bed. The loads were provided by changing the current, which created magnetic resistance on the shaft's movement. The speed of the engine was controlled by a centrifugal governor. The engine speed was regulated by a centrifugal governor. Table 2 depicts the main specifications of the engine. Two different fuel tanks were utilized to store diesel and biodiesel fuel. The engine's quantity of fuel consumed by the engine was measured by a stopwatch for the time taken to $10 \mathrm{cc}$ of fuel. To investigate the temperatures at various points on the engine, a K-Type thermocouple was employed. An AVL-444 gas analyzer was used to measure $\mathrm{CO}, \mathrm{HC}$, and $\mathrm{NO}$ emissions, and an AVL-437C smoke meter was used to measure smoke in the tail pipe. 


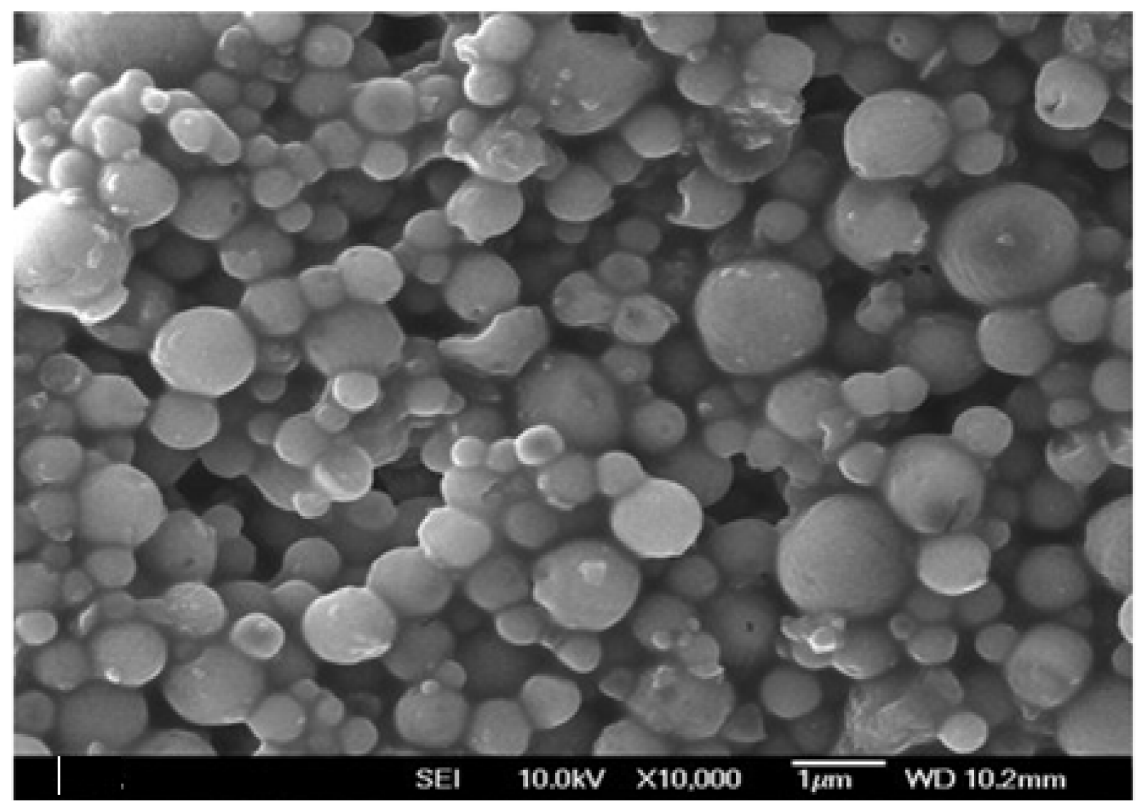

Figure 1. SEM image of alumina nanoparticle $(50 \mathrm{~nm})$.

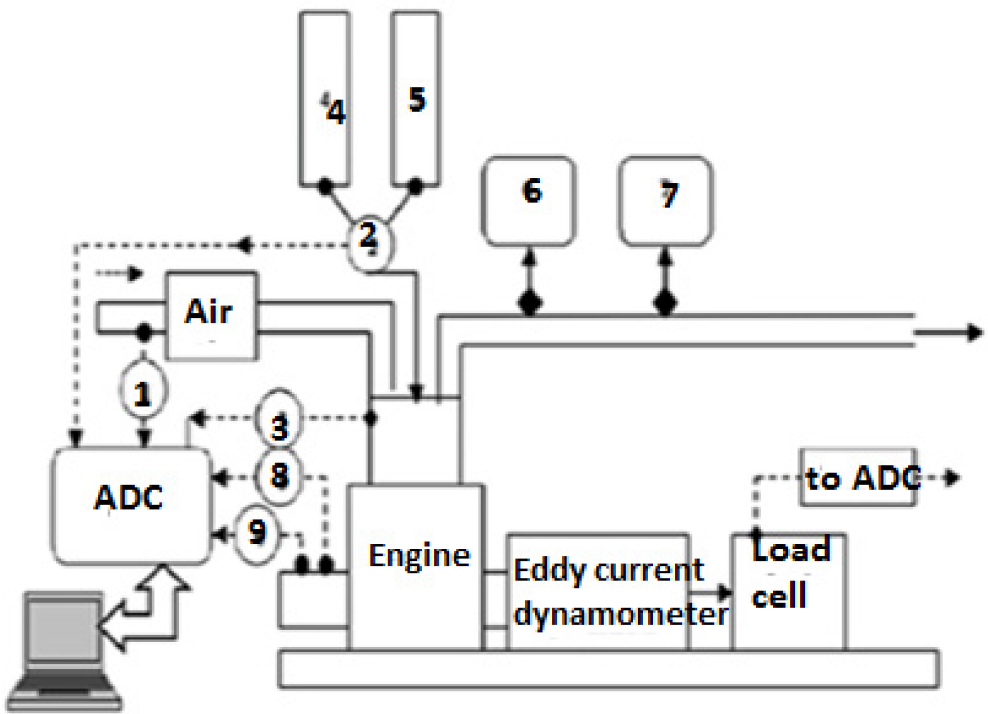

1. Air flow sensor 2. Fuel flow sensor 3.Pressure sensor

4. Diesel tank 5. Biodiesel tank 6. Five gas analyser

7. Smoke meter 8. Speed sen sor 9. Crank angle encoder

Figure 2. Engine test rig.

In the cylinder head, a piezoelectric pressure sensor was fitted to get the combustion pressure-crank angle history, an electro-optical sensor was utilized to determine TDC location, and the crank angle was gauged using a crank angle encoder. Cylinder pressure, crank angle, and TDC position are captured by a high-speed computer-based data acquisition system were employed. Table 3 represents the range and accuracy of the devices. After 5 min of loading, the performance and emission parameters of each fuel were evaluated to confirm that the measured parameters did not alter. Each test was run three times, and the average readings were obtained for computation. The relevant performance parameters, emissions, and smoke opacity for each load were documented. 
Table 2. Test engine technical details.

\begin{tabular}{cc}
\hline Make & Kirloskar \\
\hline Type of cooling & Air \\
\hline Bore diameter & $87.5 \mathrm{~mm}$ \\
\hline Stroke length & $110 \mathrm{~mm}$ \\
\hline Brake power & $4.44 \mathrm{~kW}$ \\
\hline Compression ratio & $17.5: 1$ \\
\hline Speed & $1500 \mathrm{rev} \mathrm{m}^{-1}$ \\
\hline Fuel injection timing & 230 before TDC \\
\hline Injection pressure & 200 bar
\end{tabular}

Table 3. Instruments uncertainty.

\begin{tabular}{ccccc}
\hline Instrument & Measurement & Range & Accuracy & Uncertainty \\
\hline & $\mathrm{CO}$ & $0-10 \% \mathrm{Vol}$ & $\pm 0.03 \%$ & $\pm 0.2 \%$ \\
AVL DI Gas 444 C Five & $\mathrm{CO}_{2}$ & $0-10 \% \mathrm{Vol}$ & $\pm 0.1 \%$ & $\pm 0.15 \%$ \\
gas analyzer & $\mathrm{HC}$ & $0-20,000 \mathrm{ppm}$ & $\pm 10 \mathrm{ppm}$ & $\pm 0.2 \%$ \\
& $\mathrm{O}_{2}$ & $0-22 \% \mathrm{Vol}$ & $\pm 0.1 \%$ & \pm 0.5 \\
& $\mathrm{NOx}$ & $0-5000 \mathrm{ppm}$ & $\pm 50 \mathrm{ppm}$ & \pm 1 \\
\hline AVL 437 C smoke meter & Opacity (\%) & $0-100 \%$ & 0.1 & $\pm 1 \%$ \\
\hline Crank angle encoder & & $720^{\circ}$ & $\pm 1 \%$ & $\pm 0.2 \%$ \\
\hline Pressure sensor & & $0-250 \mathrm{bar}$ & $\pm 1 \%$ & $\pm 0.2 \%$ \\
\hline
\end{tabular}

\subsection{Uncertainty Analysis}

The current engine testing included a variety of errors caused by calibration, equipment accuracy, ambient circumstances, and observer error, among other things. Uncertainty analysis is performed in order to acquire correct findings. The propagation of the uncertainty approach, often known as the root mean square approach, was used to calculate the engine system uncertainties [33]. The formula was used to determine the uncertainty of the engine performance parameters.

$$
w_{R}=\left[\left(\frac{\partial R}{\partial x_{1}} w_{1}\right)+\left(\frac{\partial R}{\partial x_{2}} w_{2}\right)+\ldots+\left(\frac{\partial R}{\partial x_{n}} w_{n}\right)^{2}\right]^{\frac{1}{2}}
$$

$R$ is a given function that is influenced by independent factors like $x_{1}, x_{2}, x_{3} \ldots x_{\mathrm{n}}$. Furthermore, $w_{R}$ is defined as the overall percentage error, whereas $w_{1}, w_{2}, \ldots w_{n}$ are the errors in the independent variables [33]. The percentages of errors for varying amounts are summarized in Table 3. An error analysis was performed using Taylor's theorem to verify the accuracy of the test findings. The overall degree of uncertainty is represented by,

$$
\begin{aligned}
\text { Overalluncertainty } & =\sqrt{\left[(\mathrm{BTE})^{2}+(\mathrm{BSFC})^{2}+(\mathrm{HC})^{2}+(\mathrm{CO})^{2}+(\mathrm{NOx})^{2}+(\text { Smoke })^{2}\right]}= \\
& \sqrt{\left[(1.0)^{2}+(1.0)^{2}+(0.2)^{2}+(0.1)^{2}+(0.2)^{2}+(1.0)^{2}\right]}= \pm 1.76 \%
\end{aligned}
$$

\section{Results and Discussion}

Initially, the test was conducted with diesel and B25, and then, the test was repeated with B25Al25 and B25Al50 fuel blends. The engine performance, emissions, and combustion parameters were measured for fuels, and the results were compared with base fuels. 


\subsection{Combustion Analysis}

\subsubsection{Cylinder Pressure}

$\mathrm{CI}$ engine peak pressure is governed by the beginning of the burning rate and controlled by the quantity of fuel burning during premixed burning stage. Ignition delay interval and mixture preparation also control premixed burning. Figure 3 depicts the differences in cylinder pressure versus crank angle for all test fuels. Peak pressure and occurrence at peak power circumstances for diesel, B25, B25Al25, and B25A150 are 69 bar at $6^{\circ}$ aTDC, 64.5 bar at $9^{\circ}$ aTDC, 68 bar at $7^{\circ}$ aTDC and 71 bar at $5^{\circ}$ aTDC, respectively.

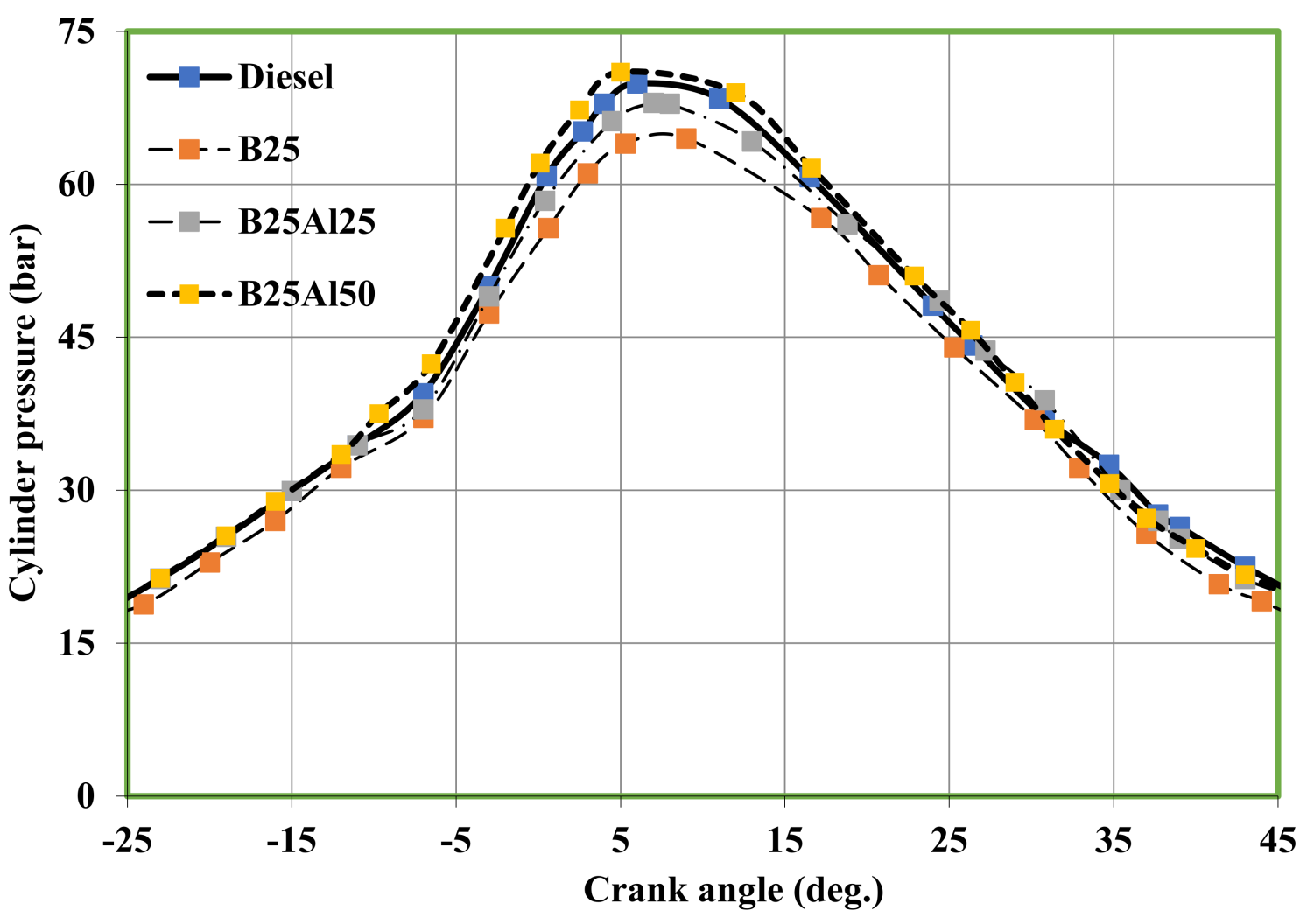

Figure 3. Changes in cylinder pressure with CA.

The lower cylinder pressure for B25 is due to its low energy content and greater viscosity when compared to diesel. For biodiesel blended with nanoparticles B25Al25 and B25A150, the cylinder pressure was increased due to more oxidation of biodieselnanoparticle mixture resulting in improved combustion leads to shorter delay period and increased cylinder pressure [30,34]. Furthermore, combining alumina nanoparticles and biodiesel resulted in a significant improvement of cylinder pressure as contrasted to a diesel and biodiesel mixture. This boost in cylinder pressure might be responsible for an increased surface area of nanoparticles and additional $\mathrm{O}_{2}$ molecules in biodiesel, which helps to speed up biodiesel oxidation. Furthermore, the enhanced air-fuel mixture promotes fuel burning within the cylinder [35]. At peak load, the cylinder pressures for diesel and B25 were 69 bar and 64.5 bar, respectively; however, when alumina nanoparticles were mixed with B25 blend in the fractions of $25 \mathrm{ppm}$ and $50 \mathrm{ppm}$ (B25Al25 and B25Al50), the cylinder pressures were 68 bar and 71 bar, respectively.

\subsubsection{Heat Release Rate (HRR)}

The HRR is computed as the combination of pressure work and the working fluid's change in internal energy [36]. The HRR is replicated by computing the chemical energy of fuels and representing the rate of post-combustion heat energy [34]. The HRR achieves its highest value at full load, demonstrating that as load grows, so does the rate of air and fuel 
mixing, resulting in a higher measure of HRR during the premixed and mixing controlled combustion phases. Due to its greater energy content than B25, diesel has a higher heat release rate than $\mathrm{B} 25$.

Figure 4 displays the changes in HRR with a crank angle for all test fuels. At peak power, the HRR reaches its maximum value. Diesel clearly has a larger HRR than B25 due to its higher energy content; an increased HRR is obvious because of the rapid combustion of diesel in the premixed stage, and biodiesel exhibited lower HRR. By incorporating nanoparticles into biodiesel, oxidation is increased, resulting in improved combustion and fewer deposits on the surface of the wall $[28,34]$. The HRR for nanoparticle-biodiesel blends was also shown to be greater than those of biodiesel and diesel. The incorporation of $\mathrm{Al}_{2} \mathrm{O}_{3}$ nanoparticles into $\mathrm{B} 25$ reduces the delay period and facilitates quicker combustion initiation. At peak power, the HRR for diesel and biodiesel is $70 \mathrm{~J} /{ }^{\circ} \mathrm{CA}$ and $65 \mathrm{~J} /{ }^{\circ} \mathrm{CA}$, respectively, but the HRR for nanoparticles-biodiesel blends B25Al25 and B25A150 is $71 \mathrm{~J} /{ }^{\circ} \mathrm{CA}$ and $73 \mathrm{~J} /{ }^{\circ} \mathrm{CA}$, respectively. Basha et al. [35] established a similar pattern of results when combining biodiesel with nanoparticles.

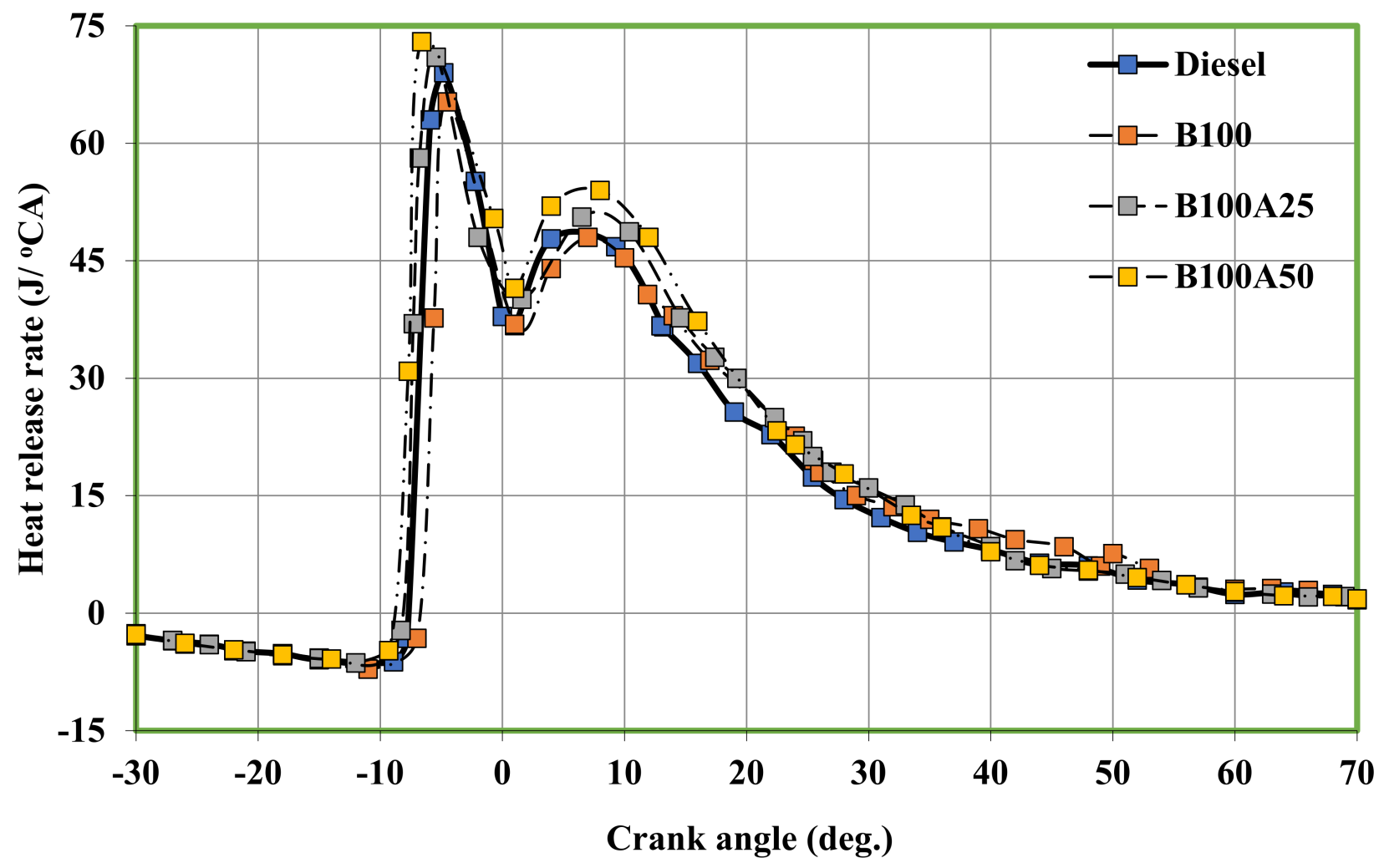

Figure 4. Changes in HRR with crank angle.

\subsubsection{Cumulative Heat Release}

Figure 5 depicts the fluctuation in CHRR for various fuels with reference to CA at peak load. The greatest CHRR was reported for B25Al50 (636 J/ ${ }^{\circ} \mathrm{CA}$ ), which is $11.2 \%, 7.4 \%$, and $7.6 \%$ greater than diesel, B25 and B25A125, respectively. The CHRR pattern of test fuels revealed substantial fluctuation in the ignition delay period, resulting in excess fuel storage during premixed combustion duration, resulting in higher CHRR levels. Maximum CHRR of diesel and B25 are $572 \mathrm{~J} /{ }^{\circ} \mathrm{CA}$ and $592 \mathrm{~J} /{ }^{\circ} \mathrm{CA}$, respectively, and for B25Al25 and $\mathrm{B} 25 \mathrm{Al} 50$, it is $617 \mathrm{~J} /{ }^{\circ} \mathrm{CA}$ and $663 \mathrm{~J} /{ }^{\circ} \mathrm{CA}$, respectively. These findings were similar to the earlier findings of Basha and Anand (2011) for biodiesel with nanoparticle mixtures. 


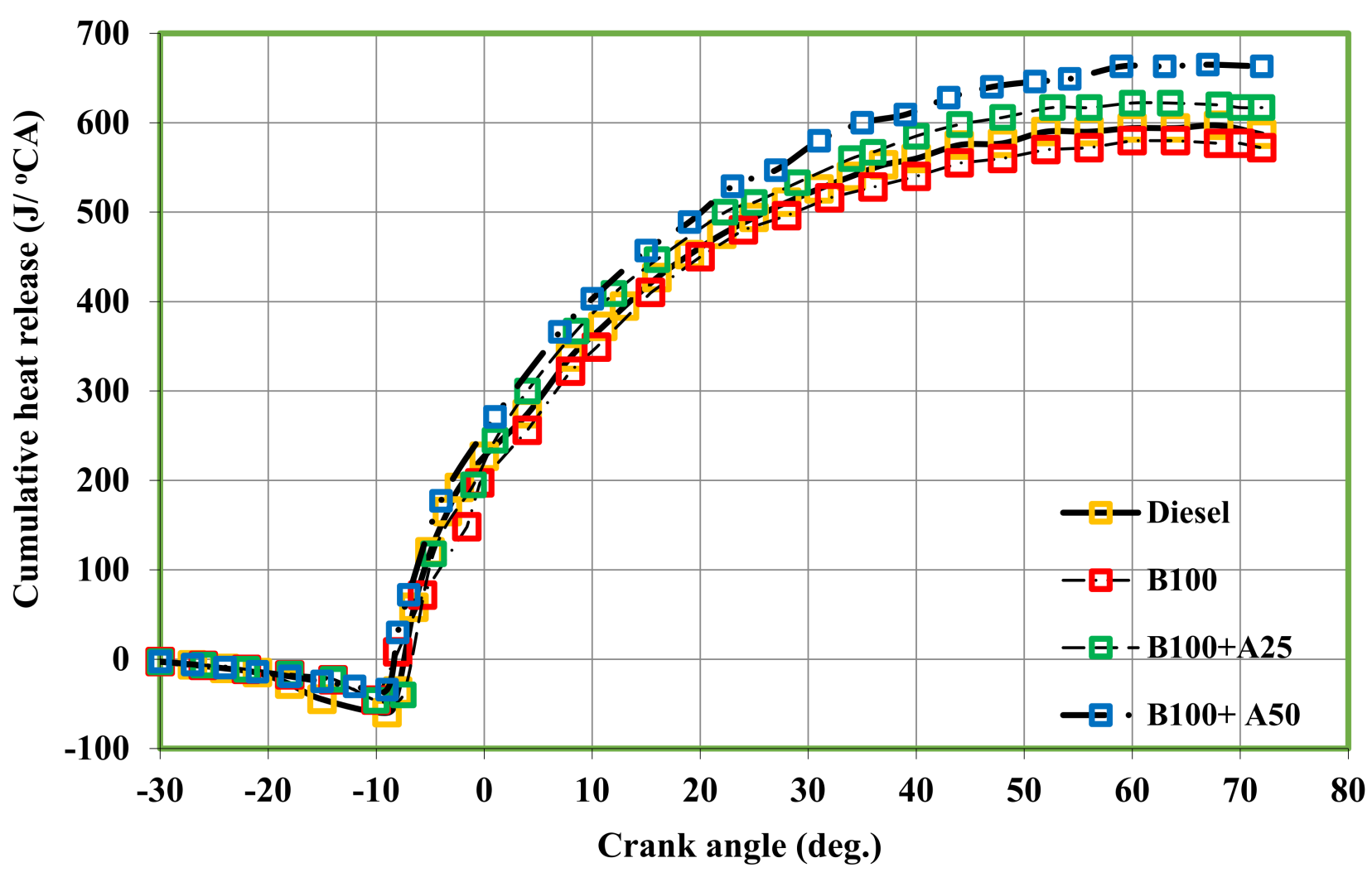

Figure 5. CHRR versus crank angle.

\subsubsection{Ignition Delay}

In terms of crank angle, the ignition delay is defined as the time between the start of combustion and the start of injection into the engine. It depicts the whole pre-combustion process at the beginning, and at the end, it shows fuel evaporation and vaporization, a greater combining rate and its atomization of fuel [36]. Change in ignition delay as a function of load for all test fuels are fuels are illustrated in Figure 6. It indicates that, when compared to all other fuel mixtures, diesel has a higher ID under all load conditions. At peak load, the shortest ID is found for B25Al50, which is $3{ }^{\circ} \mathrm{CA}, 2{ }^{\circ} \mathrm{CA}$, and $1{ }^{\circ} \mathrm{CA}$ less than diesel, B25, and B25A125, respectively. Furthermore, under peak load, B25Al25 has a smaller ID than diesel and B25. Diesel had a longer ignition delay than the other test fuels, whereas the alumina nanoparticles fuel mixtures had a shorter ID [21,34]. This would happen because higher energy content with enhanced surface tension and concentration offers improved atomization, leading to a lower delay period. At peak power, the ID for diesel and B25 are $10{ }^{\circ} \mathrm{CA}$ and $9{ }^{\circ} \mathrm{CA}$, respectively, but it is $8{ }^{\circ} \mathrm{CA}$ and $7{ }^{\circ} \mathrm{CA}$ for B25Al25 and B25Al50.

\subsubsection{Combustion Duration (CD)}

Figure 7 demonstrates the change in $\mathrm{CD}$ and brake power for all fuels. Due to the turbulence of air motion throughout the cylinder and fuel properties, the combustion duration was regulated by crank angle duration ranging from $10 \%$ to $90 \%$ mass burnt (Heywood, 2018). At peak load, the combustion duration for diesel is $44^{\circ} \mathrm{CA}$ and for B25 is $47^{\circ} \mathrm{CA}$, but it is $49^{\circ} \mathrm{CA}$ and $46^{\circ} \mathrm{CA}$ for B25Al25 and B25Al50, respectively. When compared to diesel, B25, and B25Al25, the combustion duration for B25A150 is shortened by $2{ }^{\circ} \mathrm{CA}, 5^{\circ} \mathrm{CA}$, and $3{ }^{\circ} \mathrm{CA}$, respectively. It is also worth noting that at peak load, B25Al25 has a lower $\mathrm{CD}$ than diesel and $\mathrm{B} 25$. This reduction in combustion time might be attributed to the increased surface area, which contributes to more oxidation of alumina nanoparticle mixed biodiesel, resulting in improved combustion [21,28]. 


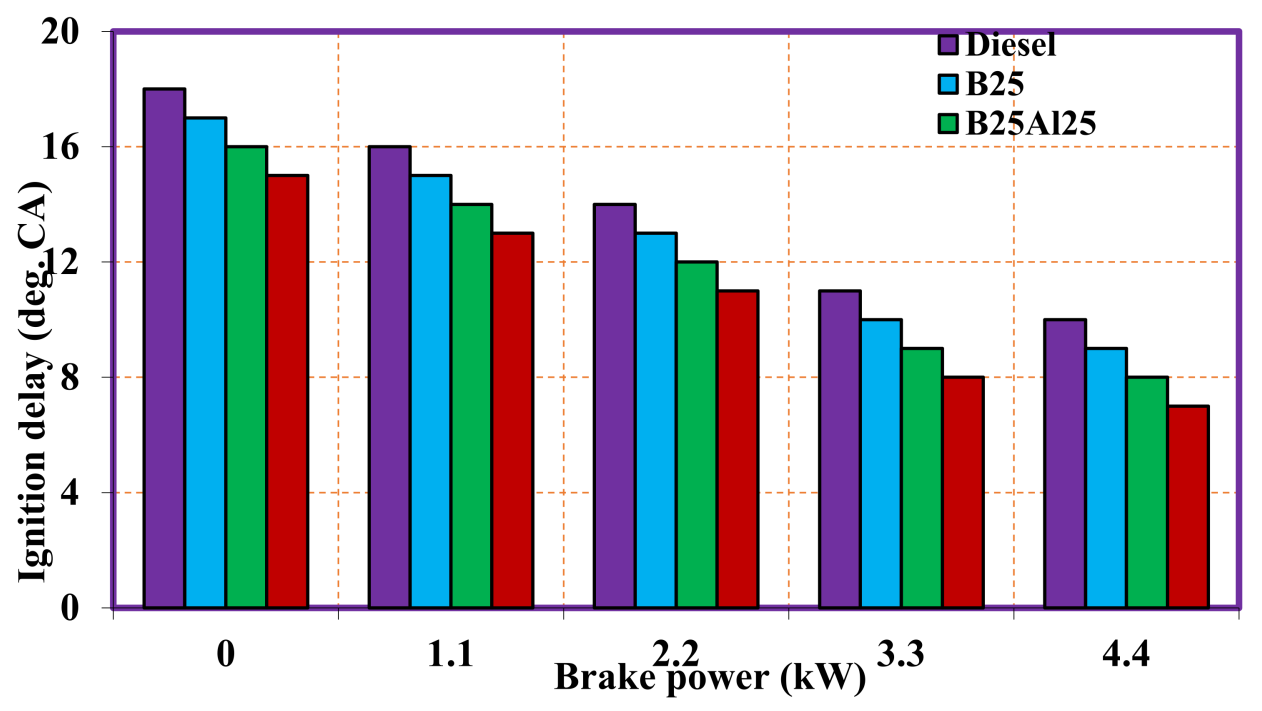

Figure 6. Ignition delay versus crank angle.

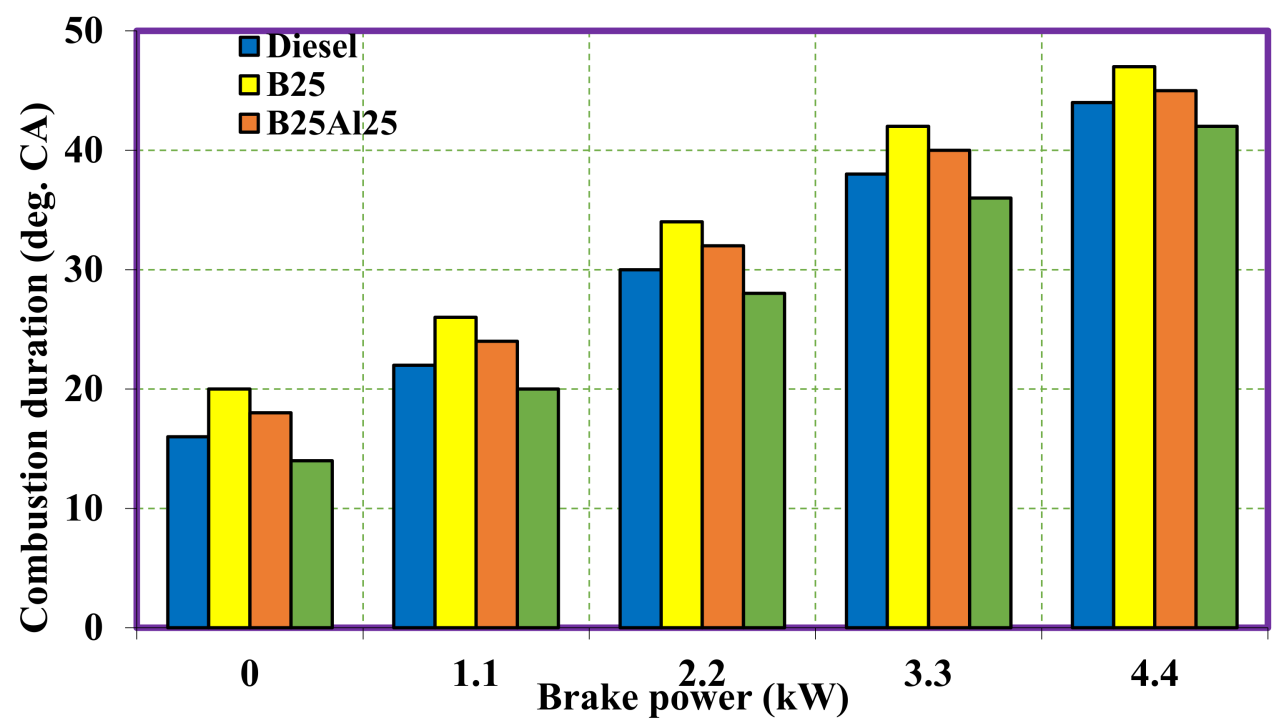

Figure 7. Changes in $\mathrm{CD}$ versus Brake power.

\subsection{Performance Analysis}

\subsubsection{Brake Thermal Efficiency}

BTE is a measure of the amount of chemical energy of the fuel is converted into productive work (Annamalai et al., 2016). BTE is influenced by heating value, and fuel usage influences BTE [36]. Figure 8 depicts the change in brake thermal efficiency (BTE) with regard to BP for diesel and biodiesel with nanoparticle combinations. It is noted that BTE ranges from 13.4 to $32.5 \%$ for tested fuels. BTE for B25 ranges from 13.4 to $29.5 \%$ between no load and peak load. BTE for diesel varies from 15.2 to $30.8 \%$ and varies from no load and peak load. BTE improves with rises in load due to reduced heat transfer and greater cylinder wall temperature. The BTE of B25 was lower than that of diesel owing to the low energy content and higher viscosity of biodiesel, which leads to poor burning of fuel. Furthermore, all biodiesel-nanoparticle combinations were shown to have greater BTE than biodiesel mix. BTE for B25Al25 rises from 13.9 to 30.3\%, whereas BTE for B25Al50 rises from 15.8 to $31.2 \%$ at no load to peak load. This could be attributed to nanoparticle absorption in biodiesel mixtures, which causes additional atomization following the nano explosion event of fuel mixing and facilitates entire combustion (Sivakumar et al., 2017). Because nanoparticles-biodiesel mixture has a shorter physical delay, a faster evaporation 
rate, a longer flame sustained, and a greater flame temperature, they improve BTE [35,37]. Moreover, $\mathrm{Al}_{2} \mathrm{O}_{3}$ nanoparticles enhance combustion and BTE by lowering ignition latency and boosting cylinder depth of penetration and mixture momentum in the combustion chamber.

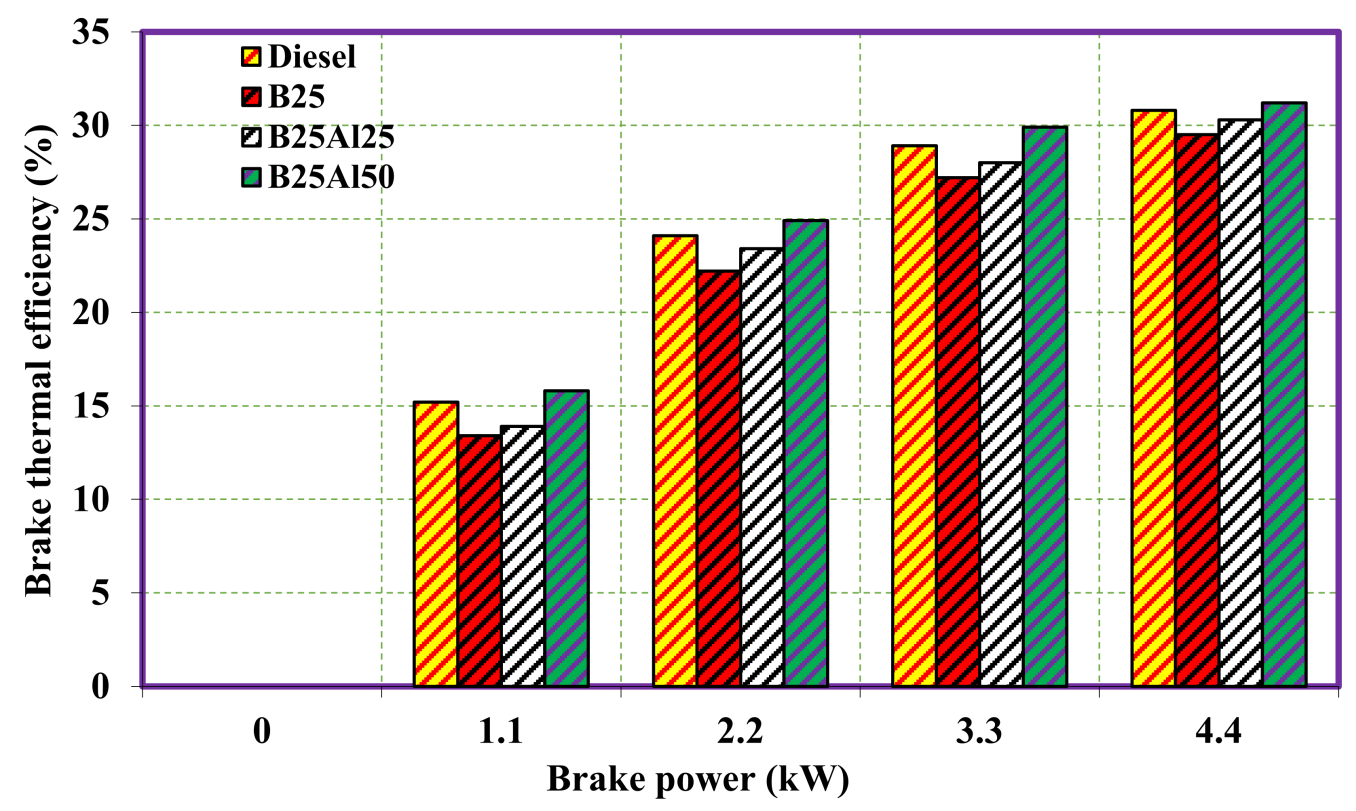

Figure 8. Brake thermal efficiency versus BP.

\subsubsection{Brake Specific Fuel Consumption}

BSFC is a measure of fuel efficiency that indicates the ratio of consumption rate to brake power. For engine operation, a lower BSFC level is preferred. The BSFC is a measuring scale used to evaluate engine efficiency in converting thermal energy from a fuel into required braking power [37]. Because of its lower energy content and higher kinematic viscosity, the B25 biodiesel blend has a greater BSFC than diesel. As a result, more fuel must be used to provide the same amount of power. Figure 9 show that all four biodiesel-nanoparticle combinations had lesser BSFC than biodiesel mixture B25.

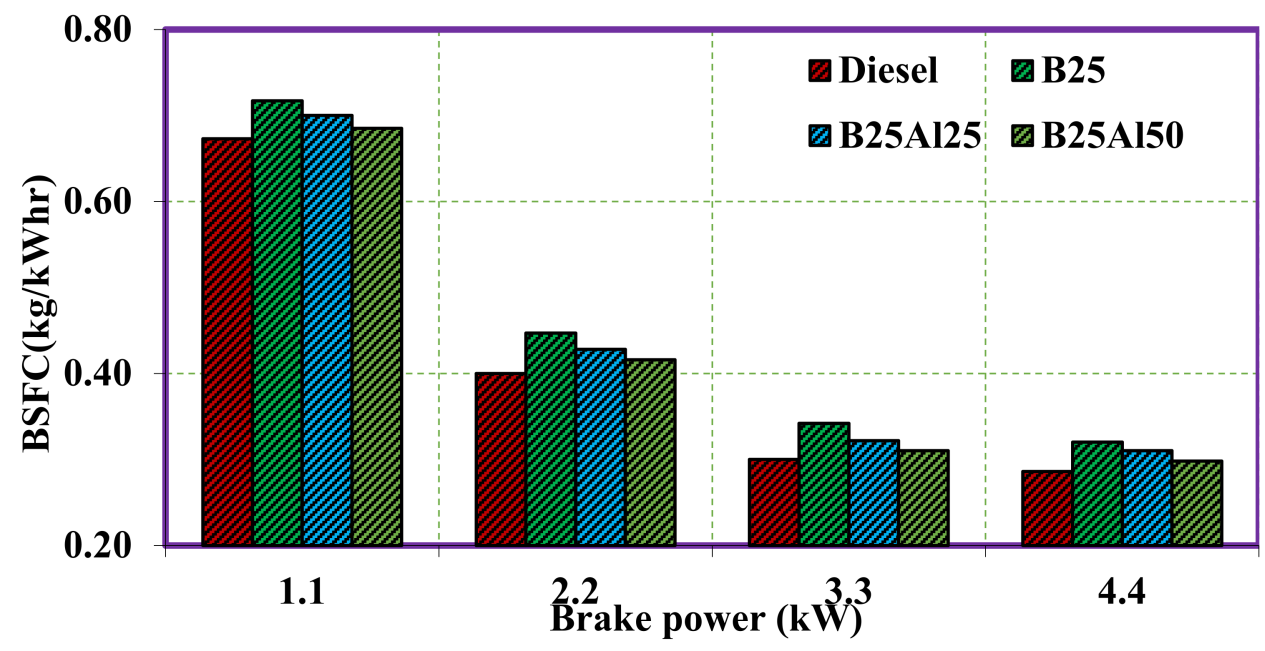

Figure 9. Changes in BSFC with BP.

The addition of 25 and $50 \mathrm{ppm}$ of alumina nanoparticles with B25 reduces the BSFC to $0.31 \mathrm{~kg} / \mathrm{kWh}$ and $0.3 \mathrm{~kg} / \mathrm{kWh}$, respectively, compared to $\mathrm{B} 25(0.32 \mathrm{~kg} / \mathrm{kWh})$. The physical properties of nanoparticles are responsible for the reduction in BSFC, which provide an 
excess of oxygen throughout the whole combustion process. The nanoparticles prevent the development of carbon deposits, which reduces cylinder friction and, as a result of the reduction in SFC [34]. Lower BSFC is also owing to the beneficial impact of $\mathrm{Al}_{2} \mathrm{O}_{3}$ nanoparticles, which undergo catalytic oxidation reactions. Furthermore, the inclusion of alumina nanoparticles in biodiesel mix increases the evaporation rates and improves biodiesel combustion. At full load, the BSFC of diesel, B25, B25Al25, and B25Al50 is $0.29 \mathrm{~kg} / \mathrm{kWh}, 0.32 \mathrm{~kg} / \mathrm{kWh}, 0.31 \mathrm{~kg} / \mathrm{kWh}$, and $0.3 \mathrm{~kg} / \mathrm{kWh}$, respectively. Moreover, BSFC found for B25Al50 is $0.33 \%$ and $6.3 \%$ lower than diesel and B25, respectively, at maximum power. Because of the increased oxidation of B25-nanoparticle mixes, these results are equivalent to those reported by Annamalai et al. [30] when nanoparticles were enriched with biodiesel mixture.

\subsection{Emission Analysis}

\subsubsection{Carbon Monoxide Emissions (CO)}

Carbon monoxide emissions are created as a result of the decreased oxygen present during burning $[30,34]$. Figure 10 indicates the effect of $\mathrm{CO}$ emission with BP for diesel, B25 mixture, and nanoparticle fuel mixes. Carbon monoxide is generated as a result of poor fuel-air mixing, concentrated rich zones, and a shortage of readily available oxygen for burning [36]. CO emissions vary between 0.04 and $0.07 \%$ from no load to full load for the tested fuels. For B25, CO emissions vary from 0.3 to $0.14 \%$ between low loads and peak power. Diesel CO emissions range from 0.05 to $0.14 \%$ between low loads and full load. As seen in the graph, CO emission reduces with increasing up to $75 \%$ of the load but rapidly jumps at peak load due to an increase in the higher injection of fuel, leading to poor burning. CO emissions produced by the B25 at full load are much lower than those produced by pure diesel. This could be because the oxygen atom present in the fuel accelerates the oxidation, resulting in better burning of biodiesel.

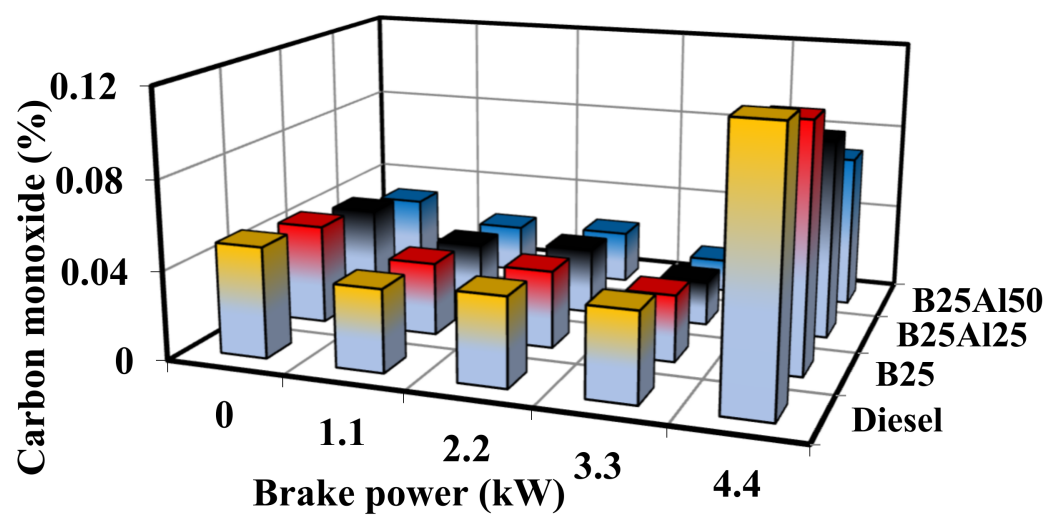

Figure 10. Carbon monoxide versus BP.

At full load, CO emission of B25Al25 and B25Al50 is 0.09 percent and 0.07 percent, respectively. Furthermore, increasing the concentration of nanoparticles in biodiesel mixes reduces $\mathrm{CO}$ emissions owing to the influence of catalytic response, which improves biodiesel oxidation and results in full combustion. Additionally, this is owing to the beneficial impact of $\mathrm{Al}_{2} \mathrm{O}_{3}$ nanoparticles, which experience catalytic oxidation reaction, therefore empowering the air-fuel mixing rate. Furthermore, at peak load, the diesel engine runs on biodiesel-nanoparticle combinations, which create reduced $\mathrm{CO}$ emissions as compared to the $\mathrm{B} 25$ blend. This is because of additional oxygen in $\mathrm{A} 2 \mathrm{O} 3$ nanoparticles, which improves oxidation and results in improved combustion and lower CO emissions. [21,30,34]. At peak load, diesel, B25, B25Al25, and B25Al50 had average CO emissions of $0.14 \%, 0.11 \%$, $0.09 \%$, and $0.07 \%$, respectively. The CO emissions of B25Al50 are $36 \%$ and $22 \%$ lower than B25 and B25Al25, respectively, at maximum load. 


\subsubsection{Hydrocarbon Emissions (HC)}

The main factors that influence HC emissions are spray behaviors, fuel qualities, and air-fuel ratio; due to limited oxygen present during burning, $\mathrm{HC}$ emissions are generated. Figure 11 illustrates the change of $\mathrm{HC}$ emission with brake power for diesel, biodiesel blends, and their nanoparticle mixtures. At peak load, according to the graph, the HC emission for the B25 is $28 \mathrm{ppm}$, while the diesel emission is $32 \mathrm{ppm}$. The addition of an extra $\mathrm{O} 2$ molecule in the molecular structure promotes oxidation and, therefore, leads to improved combustion, resulting in lower HC emissions. HC emissions from no load to peak load range from 7 to $32 \mathrm{ppm}$ for tested fuels. From no load to peak load, HC emissions for diesel range from 11 to $32 \mathrm{ppm}$ and for B25, it ranges from 9 to $28 \mathrm{ppm}$, respectively. $\mathrm{HC}$ emissions for B25 are diminished by applying 25 and $50 \mathrm{ppm}$ of alumina nanoparticles, lowering them from 8 to $24 \mathrm{ppm}$ and from 7 to $20 \mathrm{ppm}$, respectively. Alumina nanoparticles performed as oxidation catalysts, which boosted the HC oxidation resulting in lower HC emission [37].

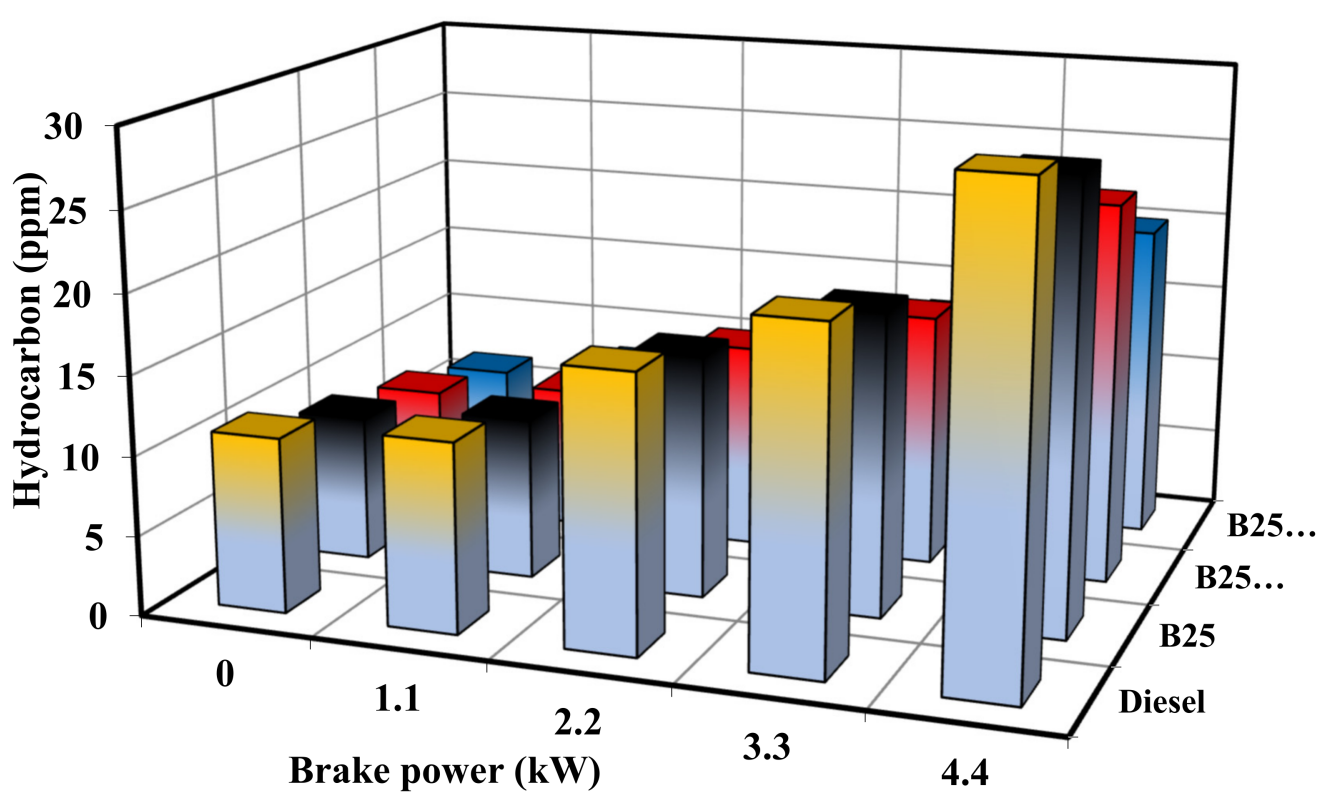

Figure 11. Hydrocarbon emission versus BP.

Furthermore, when compared to biodiesel, biodiesel with nanoparticle mixture had lower HC emissions (B25). HC emissions are 24 ppm and 20 ppm for B25 with 25 ppm and $50 \mathrm{ppm}$ alumina nanoparticle mixes, respectively. This is likely owing to an increased surface to volume ratio, enhanced enzymatic performance, and better fuel-air mixing rate, all of which result in a shorter ignition delay. In general, regardless of the proportion of nanoparticles, HC concentrations were lower than diesel and biodiesel mixtures. The inclusion of additional oxygen in the nanoparticles speeds up biodiesel oxidation, resulting in better combustion. The activation energy of nanoparticles in the mixes also burnt the carbon deposits on the wall, leading to decreased HC concentrations (Prabhu and Anand 2016). At peak power, diesel, B25, B25Al25, and B25Al50 had average HC emissions of 32, 28, 24, and $20 \mathrm{ppm}$, respectively. Additionally, the HC emissions for B25Al50 are 38, 29, and 17 lower than diesel, B25, and B25Al25, respectively, at peak power conditions. Prabhu and Anand [21] discovered comparable HC emissions patterns with biodiesel-nanoparticle combinations.

\subsubsection{Nitrogen Oxide Emission (NO)}

The main reason for NO generation is a longer residence period and a higher combustion temperature [34]. Nitrogen oxides are nitric oxide (NO) and nitrogen dioxide (NO2) 
gases involved in reacting chemically in the atmospheric air at elevated combustion temperatures (Heywood 1998). Greater NOx emissions were produced as a result of higher fuel injection to achieve high power, and the inherent $\mathrm{O}_{2}$ concentration contained in biodiesel increases oxidation, resulting in an elevated peak temperature. The fluctuation in NO emission with BP for diesel, biodiesel, and different dosages of nanoparticle mixtures is depicted in Figure 12. For all test fuels, NO emissions were obtained in the range from 214 to $1164 \mathrm{ppm}$. From the graph, NO emissions obtained for diesel in the ranges from 214 to 872 ppm from $0 \mathrm{~kW}$ to $4.4 \mathrm{~kW}$ power. NO emissions for B25 range from 242 to $960 \mathrm{ppm}$ between $0 \mathrm{~kW}$ and $4.4 \mathrm{~kW}$ power.

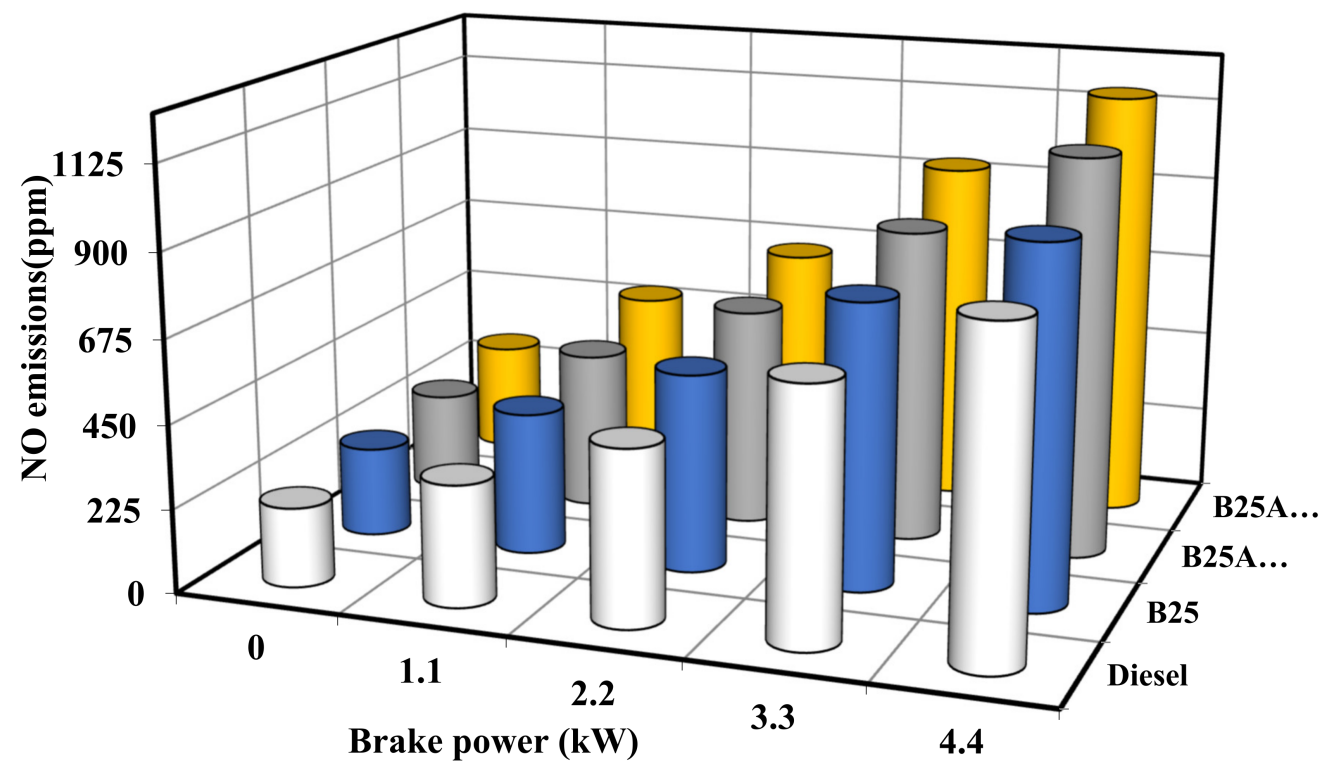

Figure 12. Nitrogen oxide emissions versus BP.

NO emissions for B25 are reduced by the introduction of 25 and 50 ppm of alumina nanoparticles, resulting in NO concentrations ranging from 268 to 1084 ppm and from 296 to 1164 ppm between no load and peak load conditions. Moreover, NOx concentrations were minimized when the engine was run by biodiesel-alumina nanoparticle mixtures. This is owing to the catalytic characteristic of $\mathrm{Al}_{2} \mathrm{O}_{3}$ nanoparticles, which allows the interaction to be performed, and the end products to be produced with thermal degradation of hydrocarbon molecules is kept to a minimum. The inclusion of nanoparticles speeds up the combustion process by raising cylinder pressure and leads to higher combustion temperature, which promotes the NO concentration [21,37,38]. At peak power, diesel, B25, B25A125, and B25A150 had average NO emissions of 872, 960, 1084, and 1164 ppm, respectively. Moreover, at peak power, the NOx for B25A150 was improved by 33\%, 21\%, and $7 \%$ as compared to diesel, B25, and B25A125, respectively.

\subsubsection{Smoke Opacity}

Because of the insufficient quantity of oxygen available for burning, smoke opacity is formed [34,37]. Figure 13 illustrates the fluctuations in smoke with BP for all tested fuels. The smoke opacity varied with increasing load, as shown in the figure, and smoke ranged from 6 to $45 \%$ for all tested fuels. Smoke obtained for B25 ranged from 8 to 34\% from zero loads to maximum load of $4.4 \mathrm{~kW}$, whereas for diesel smoke emissions ranged from 9 to $45 \%$ from low load to maximum load. Because biodiesel provides more fuel-borne oxygen, which promotes oxidation, the smoke obtained for B25 is lower than diesel at peak load [39-42]. At peak load, the smoke produced by diesel and B25 is 45 and 34\%, respectively. 


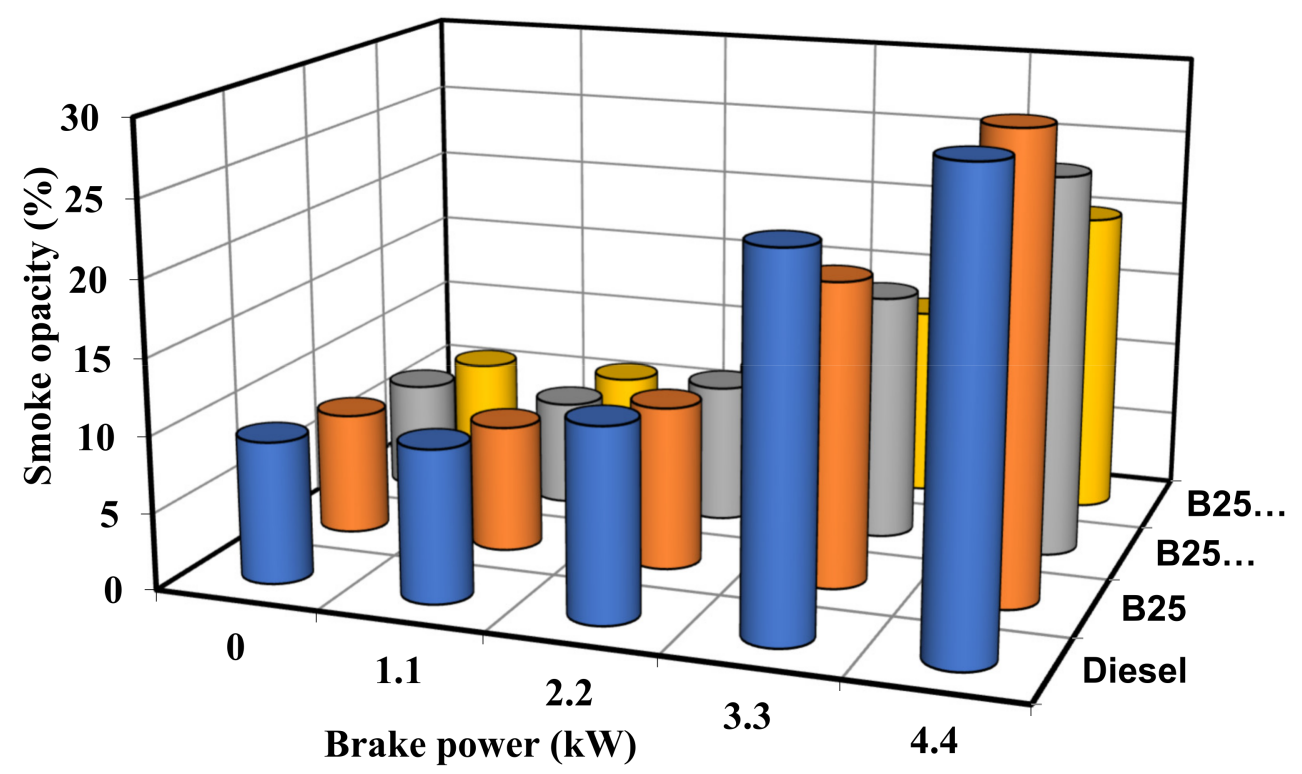

Figure 13. Smoke opacity variations against BP.

At peak load, combining 25 and $50 \mathrm{ppm}$ of $\mathrm{Al}_{2} \mathrm{O}_{3}$ nanoparticles to $\mathrm{B} 25$ decreased smoke emissions by $7-25 \%$ and $6-20 \%$, respectively. The inclusion of alumina nanoparticles to $\mathrm{B} 25$ resulted in a reduction in ignition delay, improved evaporation, and enhanced ignition properties [30]. The presence of excess oxygen in $\mathrm{Al}_{2} \mathrm{O}_{3}$ nanoparticles serves as an oxidation catalyst, resulting in a significant improvement in carbon oxidation and, as a result, a reduction in smoke output. Furthermore, integrating nanoparticles with biodiesel blend reduces the opacity of the smoke, enhances the evaporation, and enhanced fuel-air mixing results in a shorter igniting delay and quicker oxidation of B25 mixture [37-39]. At peak load, diesel, B25, B25Al25, and B10025Al50 have average smoke emissions of 45, 34, 25 , and 20\%, respectively. Moreover, at peak load, smoke for B25Al50 was decreased by $56 \%, 42 \%$, and $20 \%$ when compared to diesel, B25, and B25Al25, respectively [39,43-47].

\section{Conclusions}

In the present study, rubber seed oil methyl ester-diesel mix was mixed with alumina nanoparticles at different dosage levels. The physical-chemical properties of biodiesel were evaluated. The engine working characteristics of a DI diesel engine were examined. The following conclusions were established obtained from the experimental observations.

Enhancing the BTE of B25 by 25 and 50 ppm of alumina nanoparticles boosts the BTE from 0 to $30.3 \%$ and from 0 to $31.2 \%$, respectively. Moreover, the inclusion of 25 and $50 \mathrm{ppm}$ of alumina nanoparticles with B25 decreased BSFC compared to B25.

- Emissions of CO for B25 decreased to $0.09 \%$ and $0.07 \%$, respectively, by using 25 and $50 \mathrm{ppm}$ of alumina nanoparticles. Furthermore, introducing 25 and $50 \mathrm{ppm}$ of alumina nanoparticles to B25 diminished HC emissions from $24 \mathrm{ppm}$ and $20 \mathrm{ppm}$, respectively.

- Applying 50 ppm of alumina nanoparticles to biodiesel mixtures enhanced NO emission due to better heat capacity and enzymatic activity of nanoparticles as compared to B25. The inclusion of alumina nanoparticles to B25 resulted in a shorter ignition delay, improved evaporation, and lower HC emissions.

- Smoke opacity was decreased to $25 \%$ and $20 \%$, respectively, by putting 25 and $50 \mathrm{ppm}$ of aluminum nanoparticles to B25. The use of nanoparticles enhanced oxidation stability, heat capacity, and catalytic activity, all of which enhanced biodiesel combustion.

- At peak load, using nanoparticles with biodiesel decreased ignition delay and enhanced the cylinder pressure and HRR. Furthermore, the inclusion of nanoparticles in biodiesel decreased combustion duration owing to the higher surface area, resulting in increased fuel oxidation and hence better combustion. 
- Overall, the biodiesel blend with alumina nanoparticle mixed fuel combination may be regarded as potential alternative fuels for usage in diesel engines. Nanoparticles improve engine power while simultaneously lowering the engine's specific fuel consumption by decreasing the $\mathrm{CO}, \mathrm{HC}$, and smoke emissions.

Author Contributions: Conceptualization, S.S.K.; Data curation, K.R.; Formal analysis, V.M. and M.R.; Investigation, S.S.K., V.M., P.R. and A.A.; Methodology, K.R., M.R., P.R. and A.A.; Software, K.R. and M.R.; Writing—original draft, S.S.K., K.R. and V.M.; Writing—review \& editing, P.R., A.R., A.S., S.A.K. and A.A. All authors have read and agreed to the published version of the manuscript.

Funding: Research and completion of this paper were funded by Universiti Sains Malaysia RUi Grant 1001/PAERO/8010148.

Institutional Review Board Statement: Not applicable.

Informed Consent Statement: Not applicable.

Data Availability Statement: The data presented in this study are available on request from the corresponding author.

Conflicts of Interest: The authors declare no conflict of interest.

$\begin{array}{ll}\text { Abbreviations } \\ \text { CI } & \text { Compression ignition } \\ \text { BP } & \text { Brake power } \\ \text { BTE } & \text { Brake thermal efficiency } \\ \text { BSFC } & \text { Brake-specific fuel consumption } \\ \text { CO } & \text { Carbon monoxide } \\ \text { CO2 } & \text { Carbon dioxide } \\ \text { HC } & \text { Hydro carbon } \\ \text { NOx } & \text { Oxides of nitrogen } \\ \text { HRR } & \text { Heat-release rate } \\ \text { CRDI } & \text { Common rail direct injection } \\ \text { ID } & \text { Ignition delay } \\ \text { CD } & \text { Combustion duration } \\ \text { IP } & \text { Injection pressure } \\ \text { IT } & \text { Injection piming } \\ \text { bTDC } & \text { Before top dead centre } \\ \text { ppm } & \text { Parts per million } \\ \text { B25 } & 25 \% \text { Biodesel + 75\% Diesel } \\ \text { B25Al25 } & \text { 25\% Biodesel + 75\% Diesel + 25 ppm of Alumina } \\ \text { B25Al25 } & 25 \% \text { Biodesel + 75\% Diesel + 50 ppm of Alumina }\end{array}$

\section{References}

1. Agarwal, A.K.; Rajamanoharan, K. Experimental investigations of performance and emissions of Karanja oil and its blends in a single cylinder agricultural diesel engine. Appl. Energy 2009, 86, 106-112. [CrossRef]

2. Rajan, K.; Kumar, K.S. Improvement of Performance and Emission Characteristics of a DI Diesel Engine with Internal Jet Piston Using Palm Oil Methyl Ester; SAE Technical Paper 2009-28-0035; The Automotive Research Association of India: Pune, India, 2009. [CrossRef]

3. Ramadhas, A.S.; Muraleedharan, C.; Jayaraj, S. Performance and emission evaluation of a diesel engine fueled with methyl esters of rubber seed oil. Renew. Energy 2005, 30, 1789-1800. [CrossRef]

4. Geo, V.E.; Nagarajan, G.; Nagalingam, B.; Aloui, F.; Tazerout, M. A comparative analysis of different methods to improve the performance of rubber seed oil fuelled compression ignition engine. Fuel 2020, 280, 118644.

5. Sudalaiyandi, K.; Karthick, A.; Vignesh, K.R.; Manoj Praveen, V.J.; Madhu, P. Performance and emission characteristics of diesel engine fueled with ternary blends of linseed and rubber seed oil biodiesel. Fuel 2021, 285, 119255.

6. Ge, J.C.; Kim, H.Y.; Yoon, S.K.; Choi, N.J. Optimization of palm oil biodiesel blends and engine operating parameters to improve performance and PM morphology in a common rail direct injection diesel engine. Fuel 2020, 260, 116326. [CrossRef]

7. Ge, J.C.; Kim, H.Y.; Yoon, S.K.; Choi, N.J. Reducing volatile organic compound emissions from diesel engines using canola oil biodiesel fuel and blends. Fuel 2018, 218, 266-274. [CrossRef] 
8. Ge, J.; Choi, N. Soot Particle Distribution and Regulated and Unregulated Emissions of a Diesel Engine Fueled with Palm Oil Biodiesel Blends. Energies 2020, 13, 5736. [CrossRef]

9. Yuvarajan, D.; Ramanan, M.V. Experimental analysis on neat mustard oil methyl ester subjected to ultrasonication and microwave irradiation in four stroke single cylinder Diesel engine. J. Mech. Sci. Technol. 2016, 30, 437-446. [CrossRef]

10. Vallinayagam, R.; Vedharaj, S.; Yang, W.M.; Lee, P.S.; Chua, K.J.E.; Chou, S.K. Combustion performance and emission characteristics study of pine oil in a diesel engine. Energy 2013, 57, 344-351. [CrossRef]

11. Bajpai, S.; Sahoo, P.K.; Das, L.M. Feasibility of blending Karanja vegetable oil in petrodiesel and utilization in a direct injection diesel engine. Fuel 2009, 88, 705-711. [CrossRef]

12. Mahanta, P.; Mishra, S.; Kushwah, Y. A comparative study of pongamia pinnata and jatropha curcus oil as diesel substitute. International Energy J. 2006, 7, 1-11.

13. Rajan, K.; Senthil Kumar, K.R.; Rajaram Narayanan, M.; Mohanavel, V. Impact of nozzle opening pressure on the performance and emission behaviours of the CI engine using yellow oleander biodiesel. Int. J. Ambient. Energy 2019, 42, 1499-1505. [CrossRef]

14. Ravichandran, A.; Rajan, K.; Narayanan, M.R.; Kumar, K.S. Effect of piston bowl geometry on the performance of a diesel engine using corn biodiesel and its diesel blends. Int. J. Chem. Tech. Res. 2016, 9, 105-112.

15. Venu, H.; Madhavan, V. Influence of diethyl ether (DEE) addition in ethanolbiodiesel-diesel (EBD) and methanol-biodiesel-diesel (MBD) blends in a diesel engine. Fuel 2017, 189, 377-390. [CrossRef]

16. Rajan, K.; Prabhahar, M.; Senthilkumar, K.R. Experimental studies on the performance, emission and combustion characteristics of a biodiesel-fuelled (Pongamia methyl ester) diesel engine with diethyl ether as an oxygenated fuel additive. Int. J. Ambient. Energy 2016, 37, 439-445. [CrossRef]

17. Hossain, N.; Mahlia, T.M.; Saidur, R. Latest development in microalgae-biofuel production with nano-additives. Biotechnol. Biofuels 2019, 12, 1-6. [CrossRef] [PubMed]

18. Manickam, A.R.; Rajan, K.; Manoharan, N.; Kumar, K.S. Experimental analysis of a Diesel Engine fuelled with Biodiesel Blend using Di-ethyl ether as fuel additives. Int. J. Eng. Technol. 2014, 6, 2412-2420.

19. Zaher, F.; Gad, M.S. Performance and emissions characteristics of a diesel engine using biodiesel and N -butanol as an additive. Int. J. Appl. Eng. Res. 2014, 9, 4369-4376.

20. Lee, S.; Kim, T.Y. Performance and emission characteristics of a DI diesel engine operated with diesel/DEE blended fuel. Appl. Therm. Eng. 2017, 121, 454-461. [CrossRef]

21. Prabu, A.; Anand, R.B. Emission control strategy by adding alumina and cerium oxide nanoparticle in biodiesel. J. Energy Inst. 2016, 89, 366-372. [CrossRef]

22. Arockiasamy, P.; Anand, R.B. Performance, combustion and emission characteristics of a DI diesel engine fuelled with nanoparticle blended jatropha biodiesel. Period Polytech. Mech. Eng. 2015, 59, 88-93. [CrossRef]

23. Prabu, A.; Anand, R.B. Inhibition of NO emission by adding antioxidant mixture in jatropha biodiesel on the performance and emission characteristics of a C.I. engine. Front. Energy 2015, 9, 238-245. [CrossRef]

24. Nanthagopal, K.; Ashok, B.; Tamilarasu, A.; Johny, A.; Mohan, A. Influence on the effect of zinc oxide and titanium dioxide nanoparticles as an additive with Calophyllum Inophyllum methyl ester in a CI engine. Energy Convers. Manag. 2017, 146, 8-19. [CrossRef]

25. Najafi, G. Diesel engine combustion characteristics using nano-particles in biodiesel-diesel blends. Fuel 2018, $212,668-678$. [CrossRef]

26. Patel, H.K.; Kumar, S. Experimental analysis on the performance of diesel engine using a mixture of diesel and bio-diesel as a working fuel with aluminium oxide nanoparticle additive. Therm. Sci. Eng. Prog. 2017, 4, 252-258. [CrossRef]

27. Vellaiyan, S.; Subbiah, A.; Chockalingam, P. Combustion, performance, and emission analysis of diesel engine fueled with water-biodiesel emulsion fuel and nanoadditive. Environ. Sci. Pollut. Res. 2018, 25, 33478-33489. [CrossRef]

28. Srinivasan, S.K.; Kuppusamy, R.; Krishnan, P. Effect of nanoparticle-blended biodiesel mixtures on diesel engine performance, emission, and combustion characteristics. Environ. Sci. Pollut. Res. 2021, 28, 39210-39226. [CrossRef]

29. Arulmozhiselvan, V.; Anand, R.B.; Udayakumar, M. Effects of cerium oxide nanoparticle addition in diesel and diesel-biodieselethanol blends on the performance and emission characteristics of a CI engine. ARPN J. Eng. Appl. Sci. 2009, 4, 1-6.

30. Annamalai, M.; Dhinesh, B.; Nanthagopal, K.; SivaramaKrishnan, P.; Lalvani, J.I.J.; Parthasarathy, M. An assessment on performance, combustion and emission behavior of a diesel engine powered by ceria nanoparticle blended emulsified biofuel. Energy Convers. Manag. 2016, 123, 372-380. [CrossRef]

31. Devarajan, Y.; Mahalingam, A.; Munuswamy, D.B.; Arunkumar, T. Combustion, Performance, and Emission Study of a Research Diesel Engine Fueled with Palm Oil Biodiesel and Its Additive. Energy Fuels 2018, 32, 8447-8452. [CrossRef]

32. Devarajan, Y.; Nagappan, B.; Subbiah, G. A comprehensive study on emission and performance characteristics of a diesel engine fueled with nanoparticle-blended biodiesel. Environ. Sci. Pollut. Res. 2019, 26, 10662-10672. [CrossRef] [PubMed]

33. Holman, J.P. Experimental Methods for Engineers, 8th ed.; Tata McGraw Hill Publications: New York, NY, USA, 2012.

34. Barua, P.; Hossain, N.; Chowdhury, T.; Chowdhury, H. Commercial diesel application scenario and potential of alternative biodiesel from waste chicken skin in Bangladesh. Environ. Technol. Innov. 2020, 20, 101139. [CrossRef]

35. Basha, J.S.; Anand, R.B. Performance, emission and combustion characteristics of a diesel engine using Carbon Nanotubes blended Jatropha Methyl Ester Emulsions. Alex. Eng. J. 2014, 53, 259-273. [CrossRef]

36. Heywood, J.B. Internal Combustion Engine Fundamental; McGraw Hill Publications: New York, NY, USA, 2018. 
37. Atarod, P.; Khlaife, E.; Aghbashlo, M.; Tabatabaei, M.; Hoang, A.T.; Mobli, H.; Nadian, M.H.; Hosseinzadeh-Bandbafha, H.; Mohammadi, P.; Shojaei, T.R.; et al. Soft computing-based modeling and emission control/reduction of a diesel engine fueled with carbon nanoparticle-dosed water/diesel emulsion fuel. J. Hazard. Mater. 2020, 407, 124369. [CrossRef] [PubMed]

38. Sivakumar, M.; Sundaram, N.S.; Thasthagir, M.H.S. Effect of aluminium oxide nanoparticles blended pongamia methyl ester on performance, combustion and emission characteristics of diesel engine. Renew. Energy 2017, 116, 518-526. [CrossRef]

39. Arunkumar, M.; Mohanavel, V.; Afzal, A.; Sathish, T.; Ravichan-, M. A Study on Performance and Emission Characteristics of Diesel Engine Using Ricinus Communis ( Castor Oil ) Ethyl Esters. Energies 2021, 14, 4320. [CrossRef]

40. Kozlovskiy, A.; Zdorovets, M.; Kenzhina, I.; Berguzinov, A.; Tishkevich, D.; Zubar, T.; Trukhanov, A. The study of the applicability of ionizing radiation to increase the photocatalytic activity of TiO2 thin films. J. Nanostructure Chem. 2020, 10, 331-346. [CrossRef]

41. Rehman, Y.; Copet, C.; Morlando, A.; Huang, X.-F.; Konstantinov, K. Investigation of ROS scavenging properties and in vitro cytotoxicity of oxygen-deficient La2O3-x nanostructure synthesized by spray pyrolysis method. J. Nanostructure Chem. 2020, 10, 347-361. [CrossRef]

42. Rodrigues, B.S.; Almeida, V.A.; Claudino, C.H.; Ponce-De-Leon, C.; Bavykin, D.V.; Souza, J.S. Direct polymerization of polyheptazine in the interlamelar spaces of titanate nanotubes enhances visible-light response. J. Nanostructure Chem. 2020, 10, 363-376. [CrossRef]

43. Kareemullah, M.; Afzal, A.; Rehman, K.F.; Shahapurkar, K.; Khan, H.; Akram, N. Performance and emission analysis of compression ignition engine using biodiesels from Acid oil, Mahua oil, and Castor oil. Heat Transf. 2019, 49, 858-871. [CrossRef]

44. Samuel, O.D.; Waheed, M.A.; Waheed, M.A.; Taheri-Garavand, A.; Taheri-Garavand, A.; Verma, T.N.; Verma, T.N.; Dairo, O.U.; Dairo, O.U. Prandtl number of optimum biodiesel from food industrial waste oil and diesel fuel blend for diesel engine. Fuel 2020, 285, 119049. [CrossRef]

45. Samuel, O.D.; Okwu, M.; Oyejide, O.J.; Taghinezhad, E.; Afzal, A.; Kaveh, M. Optimizing biodiesel production from abundant waste oils through empirical method and grey wolf optimizer. Fuel 2020, 281, 118701. [CrossRef]

46. Barua, P.; Chowdhury, T.; Chowdhury, H.; Islam, R.; Hossain, N. Potential of power generation from chicken waste-based biodiesel, economic and environmental analysis: Bangladesh's perspective. SN Appl. Sci. 2020, 2, 1-9. [CrossRef]

47. Hossain, N.; Hasan, M.H.; Mahlia, T.M.; Shamsuddin, A.H.; Silitonga, A.S. Feasibility of microalgae as feedstock for alternative fuel in Malaysia: A review. Energy Strategy Rev. 2020, 32, 100536. [CrossRef] 